\title{
Fostering Development through Village Owned Enterprise (VEs) in Rural Area: A Comparative Study between Indonesia and China
}

\author{
Dicky Rachmawan ${ }^{1}$, Annisa Meutia Ratri ${ }^{2}$, Rusydan Fathy ${ }^{3}$, M. Luthfi Khair ${ }^{4}$, and \\ Hidayatullah Rabbani ${ }^{5}$ \\ \{dicky.rachmawan1992@gmail.com¹, annisa.meutia.r@gmail.com², rusydan.fathiy@lipi.go.id ${ }^{3}$ \} \\ Magister Program Student of Sociology Department, Universitas Indonesia, Depok, Indonesia ${ }^{1}$ \\ Research Center for Society and Culture (PMB), Indonesian Institute of Science (LIPI), Jl. Jenderal \\ Gatot Subroto No.10, Jakarta, Indonesia $a^{2,3,4,5}$
}

\begin{abstract}
Poverty has decreased in Indonesia since two decades which align with SDGs' goal. However, poverty still concentrated in rural area beacuse of low income generating then they tend to find better life in urban areas. Beside, Indonesia try to develop rural community with Village Owned Enterprise (VEs) and Village Funds. This paper aims to examine, to describe then to compare the significant factors that influence about between VEs policy implementation in Indonesia, and Township and Village Enterprise (TVEs) in China since 1970s with country social analysis (CSA) approach. We use desk research by gathering previous studies, popular article which explain this topic. Further, this paper found that there are several distinctions between TVEs in China and EV in Indonesia in implementation. Although this different social structure and economic environment, Indonesia Government can take several lessons to improve VEs policy in order to provide social transformation in rural area.
\end{abstract}

Keywords: Poverty, Village, Indonesia, China

\section{Introduction}

\subsection{Urbanization, low income farmer and rural poverty in Indonesia}

Indonesia is one of the highest country with urban population growth which reach at $4,1 \%$ in 2017. This rate of Indonesia's urbanization is higher than China and India which have 3,8\% and 3,1\% [1]. Many people from rural areas are going to urban areas for seeking good quality of life [2][3] with new job outside agriculture, forestry and fishery sector [4].

In facts, the decline of farmer household in Indonesia reach until 5,13 million between 2003 until 2013, this number same as with 513 thousand farmers switching their job each year [4]. Further, the number of farmers withdraw from agriculture, forestry, and fishery is increase become 5,4 million from 2008-2018 as same as average of 600 thousand farmer each year.

This condition is caused by low level income of farmers in rural areas. Average farmers household income based on arable field as primary source $(47,74 \%)$ just generate 12,4 million rupiah annually (USD \$1001,77/year with one dollars same as Rp.12.378,- in 2014) [5]. This farmer low income condition make level poverty still concerned in rural area which reach $12,85 \%$, eventhough it percentage has decreased [6][7].

Previously, from the begining of Jokowi-Jusuf Kala Era in 2015, the approach of equal distribution is a commitment of the Indonesian Government, particularly to end of poverty 
which aligned with SDG's goal no.1 [8]. However, the facts show that, even though poverty rates had decreased, the proportion number of poor people in Indonesian is still larger in villages than cities [9][10][11][12].

Furthermore, Center of Statistical Institute in Indonesia as known as BPS state percentage of poverty and people who vulnerable become poverty tend to be in live rural areas than urban areas. There are around 44,34 million people are categorized poor and vulnerable to become poor in rural area, which composed by 15,54 million poor people [10] and 28,8 million people who vulnerable to become poor in 2018 [9].

So, it is interesting to see how Indonesia Government trying to end or to minimize poverty particularly in rural areas with village funds and village owned enterprise (VEs) as parts of Nawacita Strategy. In next part, we will give a glance of Nawacita Strategy and method include theoretical framework that we used.

\subsection{Nawacita strategy: developing Indonesia from the edges}

The Nawacita or a national development agenda in Indonesia that start from the President;s vision of the nation's sovereignty has set an ambitious target of reducing poverty, inequality, and other national development priority. The government commitment in development by more focus from border or outer-ring or rural areas. Decentralization or regional autonomy becomes one of the instruments through village fund in order to alleviate social gap among societies. The regional autonomy policy could be an entrance enhance the distribution and development not only in the big city but also until the smallest unit of government at the village level.

Further, Village Owned Enterprises (VEs) also is a strategic mechanism to create welfare by collecting local potential in social, natural, economic capital from the community itself. VEs becomes program to support regional autonomy by the mission to increase rural economic development as well as other problems in urbanization and poverty. VEs have all aspects of empowerment, including economic, institutional, managerial economic networks development, and the development of economy in downstream sector [12].

Incorporating with Village Fund, VEs could empower community based on the idea that community needs in making change and preventing undesirable things also political will with the ability of village government and community in implementing development plan [13]. In fact, the VEs is also a part of strategies in another country like China. The VEs in China already had similar policy in boosting rural development through Township and Village Owned Enterprise (TVEs) by 1978. Even though, China and Indonesia have different socialeconomic and environmental condition, communities in both countries lack individual resources to elevate themselves to a decent socioeconomic status and have significant poor population [14].

Thus, comparing between two countries is interesting in order to learn how rural development strategy through implementation of VEs and take a lesson learned to foster development in rural area. This paper is concerned with the strategy to foster rural development through VEs in Indonesia and China by looking at policy and implementation aspects.

\section{Methodology}

By using qualitative approach [15], this paper is based on secondary data in which author collected by using multiple data sources from government reports, news sources, and published studies and articles. To analyse qualitative data, this paper used several techniques 
such as data collection, data reduction, data organizing. This paper focus on VEs policy in Indonesia and China with country social analysis (CSA) [39]. We use this approach specifically on institution and good governance dimension to identify factors of VEs implementation. Then we will compare the factors between Indonesia and China.

The paper proceed as follows, first section focusses on explain and examine the implementation of village funds and the emerging of Village Owned Enterprise (VEs) in Indonesia. On the second section, we will elaborates the strategy on fostering rural development through VEs in China as success story. The success story of China can be a lesson learn to develop VEs in Indonesia. Further, the conclusion also reflects on the differences between the implementation of rural poverty ending program with VEs in China and Indonesia. Then we continued with discussion which we must see the possibility or the requirement to acquire the success story in Indonesia.

\section{Result and discussion}

\subsection{Build Indonesia from the edges}

\subsubsection{Village fund and village owned enterprise (VEs)}

Indonesia government has strong ambition to improve village community welfare based on Law no.6/2014 about Village [16] and to build Indonesia from the edges as one of Nawacita framework with village funds. Village Funds are central government funds which transferred for Villages through the local government such as Regency/City and prioritized for: implementation of development; and village community empowerment.

Unfortunately, village funds which goal to improve quality life of villager are emphasized to build infrastructure like $121,709 \mathrm{~km}$ of village road, 1,960 km of briges, 5,220 village market, etc [17]. Further, in general the implementation of Village Funds that went poorly among them highlighted the lack of priority scale planning by both the Government and community institutions in the Village, the weak capacity of Village Government, the absence of public participation in overseeing budget use, the complexity of administrative matters, the lack of village capacity in providing assistance funds for the Village Fund, and poor coordination between related parties [18][19][20][21][22][23].

Beside lack of village funds implementation, there is another factor which make it worse. Indonesian Corruption Watch (ICW) has showed the increasing of corruption cases relate with this program from 17 cases in 2015 become 96 cases in 2017 . From total 154 cases, Village Heads are the dominant actor who manipulate village funds especially in political year [24].

Apart from a number of problems and challenges in the implementation of the village fund, we underline a number of things; first, the village fund should balance the implementation of the physical development-components with the community empowermentcomponents of itself; second, the effectiveness of the implementation of the village fund must give more attention for the readiness conditions of communities and village priority; and third, the implementation of the village fund must emphasize the dimensions of accessibility, participation and freedom in a policy scheme to encourage policies that are truly bottom up and inclusive. Therefore, the existence of Village-Oewed Enterprise (VEs) is becoming increasingly significant in its constellation with the implementation of the village fund and efforts to achieve equitable distribution of community welfare. 


\subsubsection{Implementation of Village Owned Enterprise in Indonesia}

Village Owned Enterprise is a development strategy that based on Law No.32/2004 about Local Government, Law no.6/2014 about Village and Underdeveloped Regions and Transmigration regulation no.4/2015 about Establishment, Management or Dismissal of Village Owned Enterprise (VEs) that state "The village can establish a village-owned business entity in accordance with the needs and potential of the village". Village Owned Enterprises (VEs) or BUMDes (Badan Usaha Milik Desa) are the pillars of the welfare of the nation based on a spirit of brotherhood and mutual cooperation [25]. VEs is founded on a shared commitment of the community and to cooperate together in order to realize economic welfare and prosperity of rural communities. Through VEs, Village could develop various types of business in service, distribution, trading an agricultural product and also small-scale industry/ household industry. The VEs is defined by Village regulation and under advanced role of village authorities and open for larger community participation.

Village owned enterprise is projected to be new economic strength in rural development of Indonesia. Before VEs, there are a bunch of programs for boosting the rural development, such as National program for Community Empowerment or PNPM. However, VEs is coming with the new approach to drive a rural economy by establishment economic institution that manage entirely by the rural community and based on village or local potential. Generally, there are several characteristic of VEs in Indonesia, for instance: the VEs is owned and managed together by village government and community, the capital source is from village budget and from villagers as equity (share or stock), strong consideration based on local wisdom, business based on the local potential, using village policy to share the benefits, Facilitated by government in all level authority, control mechanism and implementation is based on collective agreement such as village consultative assembly [26].

The VEs play both economic and social function. Thus, the implementation should refer to the regulation that VEs should manage based on based on cooperative, participative, emancipative, transparence, accountable and sustainable [27]. VEs are utilizing local potential in supporting the village economy and the welfare of the community as follows: a. VEs Karangkandri Sejahtera in Cilacap that using Steam Power Plant (PLTU) as a business opportunity, VEs become suppliers of various PLTU needs; b.VEs Tirta Mandiri, which successfully built the swimming pool that originates from the potential of the village's natural water in Klaten [28].

Unfortunately, not all the existing VEs are active and perform based on the role and function ideally. Total VEs in Indonesia reach to 39.149 unit, however in reality approximately around half of that number ( \pm 19.574 unit) in torpor condition [29]. Even though central government had given lot of investation around 60 trillion or same as 800,4 million rupiah for each village [17][30]. This condition creates number of cases related to VEs implementation. there are many complaints about the VEs implementation in Indonesia such as about lack of capabilities or mismanagement of VEs, abuse of authority, fraud, and project based, no room for community participation, etc. For instance, the case in one of VEs in Aceh, there was a problem related to the indication of mismanagement of fund and fictitious organization. In addition, in Lampung there are VEs established since 2018 but until 2019 there were no financial reports [31]. It shows that management of VEs have a lot of issues in case of Insufficiency of internal control system and not transparent [30]. It is because of lacking community knowledge and distrust on the VEs systems [32][33][30]. Further, VEs have not been fully socialized to all villagers in various parts of Indonesia [13]. 


\subsection{Township and village owned enterprise in China}

\subsubsection{A Glance of township and village enterprise in China}

Same as Indonesia, China faced up to unemployment problem specially in rural areas in 1950s. This problem emarged because of rural reform in Maoist Era known as "The Great Leap" campaign which focused on food security and underminded organic network on agriclutural processing [34][35]. In the end of 1950s China deploy new policy that focus on "industy by people" named "Communie and Brigades Entepreneur" (CBEs) as forerunner of "Town Village and Township Enterprises" (TVEs) [35].

As well as we know about VEs/BUMDes in Indonesia, TVEs in China has same and different characteristic with BUMDes. The same side is TVEs is a economic unit which collective owned by people of a village, in contrast TVEs in China can be a business unit which controlled by individual but it use "village goverment business robe" as community business that categorized as "Geti" [36][35].

Beside that little different conception of BUMDes and TVEs, the TVEs has significant role as transformation economic agent and contributor for economic growth for China since 1978 [37][38]. Same as expectation of BUMDes's role conception in Indonesia, TVEs had proven their role as enhencing rural income, supplying huge employement for rural workforce and decreasing inequality economy between rural and urban area [37][39][38][40][36].

These are several significant role of TVEs in China. TVEs' production contributed $50 \%$ in industrial added value which reach $30 \%$ GDP of China in 1995. Total output from TVEs' increased with average in 21\% each year from 1978-1995 and holding added value growth more thatn $18 \%$ in 1996-1997 [40]. In 1999 TVEs' export touch $48 \%$ of total export with annually average growth in 1988-1999 around 28\% [9]. In employment aspect, there are 1,4 millions TVE with 30 millions employee in 1980 which developed become 127 millions employee in 2000 (this number same as $18 \%$ total workfoce or $25 \%$ rural workforce in China) [37]. From these evidences of significant role in economic growth from TVEs in China, maybe Indonesia can take several lesson and copy-paste this policy process implementation to get economic growth in future. Because, altough any deloping countries can copy-paste this policy, they must see the context between China and the country which want to use this model [39].

\subsubsection{Communie and brigade enterprise (CBE) as failed top-down policy into township and village enterprise (TVEs) as success story}

In erlier time of decentralization wave, central government in China created CBEs in 1950 with hierarchy structure for develop rural industry which recource come from community itself [35]. In the first CBEs had fast development and employed arround 18 million people which have product value until six billion yuan. This section firstly focus on agriculture industry to prevent rural people left agriculture sector and pushed industry to serve agriculture [38]. Agriculture industry had role to supply peseant need for agriculture production which five target small industry include "iron and steel, cement, chemical fertilizer, microhydro power plant, and things for farm" [38].

Unfortunately, with top-down policy CBEs not really implemented as it expected by central government to replace heavy industry. In implementation, this industry was not absorb many rural workforce who mainly work as farmer because of particular employment standard [38]. Further even there were several costumer, yet without clearness of market and regulation made many CBEs producted peculiar and unstandardized things [39][38][35]. In hence, 
central government shut down many CBEs activity in 1965 to formulate proper policy for developing rural industry [38][35]. The number of CBEs falling drastically from 117 thousands to eleven thousands CBS [35].

Economic reform for rural industry re echoed in end of 1970 s by China government, then CBEs transform become TVEs in 1984 to agriculture modernization [39]. TVEs established by village resident and respresented by village government which delegate management to TVEs manager with contract [39][37][38][35]. Sometimes several TVE recruiting engineer for technical support and production efciency [37].

After agriculture modernization, in 1979 central government of China change their policy about rural industry. The new rural industry approach was allowing any TVEs to do their business if it rationally economic value for support agriculture products with standardized products, then many TVEs gradually toke this opportunity [37][35]. World Bank estimated TVEs contribution arround 25\% GDP for China in the middle 1980-1990s. Export value that came from TVEs reach $\$ 8$ bilions USD in 1988 and it increased become $\$ 84,3$ billion USD in 1997. Revenue sharing from national export had sourced by TVEs increased from $16,9 \%$ in 1988 to $46,2 \%$ in 1997 [35].

Behind this success stroy of TVEs in China, we must see the reallity of the implementation. It was not an impact from carefully designed plan or policy. Furhtermore, this success story is long learning process from pragmatic nation with their value (include government and their people) who want to improve their condition and learn form mistakes, so they can improve their capabilities to avoid the previous mistakes. There are several studies that examine the success story of TVEs in China that we can learn too as Indonesian who have BUMDes.

\subsubsection{The factors to reach success story: good environment for TVEs growth}

Good environment is the most basic and the most essential factor for TVEs growth in China. Previous studies are underline this factor in different term, Naughton [37] who identificate five factors which make fast growth for TVEs. The five factors from Naughton are: 1) Good basic social-economic condition; 2) Pragmatic policy; 3) Good institutional environment; 4) Revive of old socio-economic network; and 5) Flexibility organization of TVEs. For Naughton (2007) effective reform of rural industry can be implemented by pragmatic government based by strong ambition.

Other perspective identified three theory which explain how TVEs can have fast growth between 1978 until 1999. Contractual agreement between Village Government as village community representation with TVEs manager that result of efficiency production [39][37], furhter of efficiency production Weitzman and $\mathrm{Xu}$ offer theory of income distribution that strenghening social contract between villager and village [39]. Comparable with Naughton [38] who said about good institutional environment and good basic socio-economic condition, the third theory by Field et.al [39] said about "the policy which give TVEs capability to adapt and configurate with their external environment". Identical with good basic condition of socio-economic from Naughton [38] as good environment, further Fu and Balasubramanyam [37] mention about "cooperative culture" which based on social values particulary in confucius value. From this point we can figure it out that several previous studies have sliced up one to each other. So, what really happend in the good environment for TVEs growth?

In China context at that time village government tend to find their source of funds by themselves. Despite limited resource to starting new business in particular for taking loans from government bank, so village government (VG) had become as protector, guarantor for TVEs when taking loans from bank or traditional financial group. 
Strating new business must have many risks, so VG recruiting experienced manager from urban area to ensure their TVEs would running well and give them sharing profit as feedback [40]. Moreover VG facilitated TVEs on finance and loan payment system beside encouraging them with incentive, creating accountability and discipline atmosphere, and strugling to product international quality things to become good enterpreneur [39][37][40][35].

Additionally, there was role of SOEs (State Owned Enterprise) for TVEs to support them with cheap resources and subcontracting work which gave benefit to each other enterprise [40]. Further higher government like county until central government promoted TVEs to domestic or international investors [39]. In the end of process, government facilitated TVEs with high integration market bind with international market, this is the reason after TVEs improve their goods quality then they can exporting their goods in the world [40]. There are several expample about high integration international market such Datang Township which product and supply arround $1 / 3$ soacks in the world, $40 \%$ ties producted by Shengzhou Township, and more than $70 \%$ buttons producted by Qiatou Township.

If we compare between implementation of Indonesia's VEs and China's VEs, we can see different of several factors which give contribution in the table below:

Table.1: Different Factors of TVEs implementation in Indonesia and China

\begin{tabular}{ccc}
\hline Factors & Indonesia & China \\
\hline Regulation & Support VEs & Support TVEs \\
\hline $\begin{array}{c}\text { Tendency of } \\
\text { State's Role }\end{array}$ & Regulator and Source of Funds & Regulator and Facilitator \\
\hline $\begin{array}{c}\text { Accountability } \\
\text { and Capacity }\end{array}$ & $\begin{array}{c}\text { Low with low internal control (VG } \\
\text { tend to be manipulator actor in } \\
\text { political event) }\end{array}$ & $\begin{array}{c}\text { VG as Guarantor of TVEs financial } \\
\text { performance }\end{array}$ \\
\hline $\begin{array}{c}\text { Participation } \\
\text { of people }\end{array}$ & Lack (distrust people with VG) & $\begin{array}{c}\text { Engage (cooperative value to } \\
\text { Government from people) }\end{array}$ \\
\hline $\begin{array}{c}\text { Emphasizes } \\
\text { Support form } \\
\text { relate }\end{array}$ & $\begin{array}{c}\text { Complex administration for } \\
\text { liability report }\end{array}$ & $\begin{array}{c}\text { Build accountability, discipline } \\
\text { atmosphere to gain international } \\
\text { quality product }\end{array}$ \\
\hline stakeholder & parties & $\begin{array}{c}\text { State owned enterprise support VEs } \\
\text { with low cost material and promoted } \\
\text { by County or Province government }\end{array}$ \\
\hline Source: processed by authors from previous studies &
\end{tabular}

\section{Conclusions}

There are several aspects that different context between Indonesia and China. We know China has different ideology from Indonesia. China has socialism with great power of government and cooperative culture in grass root level in their society. Contrast with it, Indonesia has democratic Pancasila with not really influential government and high potential speculative actor in implementation from actor who has political power.

So, top-down policy like village funds and government budget for establish or empower VEs are inevitable easily to be manipulated in Indonesia. In additions with not really influential government for ensuring the quality of implementation for village funds and VEs make worse the condition. From this point, policy like law or local government law further to implement the policy such as establishment VEs just a "gate" not a finish points to end or minimize rural poverty in Indonesia. It will just be a potential conception if we implement it without good governance and good environment as the most essential factor. 
China has success through this process and learn by mistake from each stage by used pragmatic paradigm and full fill what the community need for adaptation. Moreover, their people have value to cooperate and adding the value with accountability and discipline to withdraw from poverty. This is the second factor that Indonesia need to learn for rural transformation thought creating people with accountability and discipline value. After government can create people with this standard, then government can apply the standardization for goods and promote it in larger market.

The third factor which Indonesia can learn from China to developing VEs is approach and implementation of "total" or "universe" element support rural villager with their VEs. Experienced worker/expert can be a manager for VEs to ensuring that VEs will be running in good plan. VEs in China get helped from SOEs to get cheap price of source and VEs get subcontract from SOEs as mutual relationship to increase efficiency and effectiveness. Finally, to ensure this policy, central government must ensure with high internal control system in implementation in village level.

\section{References}

[1] Y. Sukmana,. "Sri Mulyani Ungkap "Kegilaan" Urbanisasi di Indonesia". Kompas.com, 23 March 2017, Available: https://money.kompas.com/read/2017/03/27/142000926/sri.mulyani.ungkap.kegilaan.urbanisas i.di.indonesia. (Accessed 28 July 2019)

[2] T. Ju Lan, Soewarsono, A. Hadi, W.R. Jati, A. Ulya, I. M. Nadhiroh, and M. Amelia, "Indeks Kerentanan dan Profil Rumah Tangga Miskin”, LIPI Press, Jakarta. (2018)

[3] D. Santoso, "Penduduk Miskin Transient. Masalah Kemiskinan yang Terabaikan", Yayasan Pustaka Obor Indonesia, Jakarta. (2018)

[4] A.R.M. Umar, "Petani dan Problem Pembangunan di ASEAN", Indoprogres, 1 April 2015, Available: https://indoprogress.com/2015/04/petani-dan-problem-pembangunan-di-asean/ (Accessed 22 July 2019)

[5] Badan Pusat Statistik (BPS), "Hasil Pencacahan Lengkap Sensus Pertanian 2013 dan Survei Pendapatan Rumah Tangga Usaha Pertanian 2013”. Berita Resmi Statistik No.54/07/Th. XVII, $1^{\text {st }}$ Juli (2014).

[6] Badan Pusat Statistik (BPS), "Berita Resmi Statistik". Badan Pusat Statistik, Jakarta (2018).

[7] Badan Pusat Statistik (BPS), "Profil Kemiskinan di Indonesia Maret 2019". Jakarta: Indonesia. Available:https://www.bps.go.id/pressrelease/download.html?nrbvfeve=MTYyOQ\%3D\%3D\& $\underline{\mathrm{sdfs}=l d j f d i f s d j k f a h i \& \text { twoadfnoarfeauf }=\text { MjAxOS0xMS0wNyAyMDozNzo0OA\%3D } \% 3 \mathrm{D}}$. (Accessed 21 August 2019).

[8] W.D. Jong, B. Pokorny, P. Katila, G. Galloway, and P. Pacheco, "Community Forestry and the Sustainable Developments Goals: A Two Way Street". Forest, 9, 331. 1-18. doi:10.3390/f9060331. Available: www.mdpi.com/journal/forests (2018)

[9] Antara, "Warga Rentan Miskin 20,19 Persen dari Total Penduduk", Tempo.co, $17^{\text {th }}$ January. Availabel: https://bisnis.tempo.co/read/1165738/2018-warga-rentan-miskin-2019-persen-daritotal-penduduk/full\&view=ok. [Accessed 20 August 2019].

[10] I. Ibrahim, "Persentase Kemiskinan di Perdesaan Masih Dua Digit", Jawa Pos. Available: https://www.jawapos.com/ekonomi/15/07/2019/persentase-kemiskinan-di-perdesaan-masihdua-digit/. (Accessed 22 August 2019)

[11] A.F. Noor, "BPS: Kemiskinan di Desa Lebih Tinggi dari Kota". Republika.co.id, 15 January 2019. Available: https://www.republika.co.id/berita/ekonomi/keuangan/19/01/15/pld7ed377bps-kemiskinan-di-desa-lebih-tinggi-dari-kota. (Accessed 20 August 2019)

[12] Sekertariat Kabinet Republik Indonesia (Setkab), "Village-Owned Enterprises Expected to Boost Economy in Villages". Available: https://setkab.go.id/en/village-owned-enterprisesexpected-to-boost-economy-in-villages/ (Accessed 23 July 2019)

[13] H. G. Kusuma, and D. Krisnadewara, "Innovation Challenges of Village-Owned Enterprise". KINERJA Volume 23, No. 1, Page. 54-66. (2019) 
[14] R. Mustapha, "Workforce education and development in East Asia and the Pacific". In J.W. Rojewski (Ed), International perspectives on workforce education and development. Information Age Publishing, Greenwich, CT. (2004)

[15] U. Flick, "The SAGE Handbook of Qualitative Data Analysis". Sage, London. (2014)

[16] Law no.6/2014 about Village

[17] Kementerian Pertanian, Daerah Tertinggal dan Transmigrasi (Kemendes PDTT), "Pengelolaan Dana Desa dan Penguatan BUM Desa dalam Perekonomian Desa", Available: https://www.djpk.kemenkeu.go.id/wp-content/uploads/2017/12/2.-Menteri-Desa_Bahan-SosPenguatan-BUM-Desa.pdf. (Accessed 19 August 2019)

[18] M. Octarian, and M. Samma, "Implementasi Program Dana Desa (ADD) dalam Pemberdayaan Masyarakat di Desa Punagaya Kecamatan Bangkala Kabupaten Jeneponto". Jurnal Ilmu Pemerintahan Otoritas, Vol. 3, 1, 67-74. (2013)

[19] A. Mustanir, and Darmiah, "Implementasi Kebijakan Dana Desa dan Partisipasi Masyarakat dalam Pembangunan di Desa Teteaji Kecamatan Tellu Limpoe Kabupaten Sidenreng Rappang". Jurnal Politik Profetik, Vol. 4,2, 226-238. (2016)

[20] R. Listiyani, and A. Pambudi, "Efektifitas Implementasi Kebijakan Penggunaan Dana Desa Tahun Anggaran 2015 di Desa Gunungpring Kecamatan Muntilan Kabupaten Magelang". Jurnal Ilmu Administrasi Adinegara, Vol. 5, 7, 1-12. (2016)

[21] M. Akbar, and I. Prabawati, "Implementasi Kebijakan Dana Desa di Desa Seppong Kecamatan Tammerodo Sendana Kabupaten Majene.” Jurnal Ilmu Administrasi Negara Publika, vol. 6, no. 8 (2018).

[22] S. K. Wardhani, "Implementasi Alokasi Dana Desa Tahun Anggaran 2016 di Desa Sendangadi Kecamatan Melati Kabupaten Sleman Menurut Peraturan Bupati Nomor 6 Tahun 2015". Fakultas Hukum Universitas Islam Indonesia, Jogjakarta. (2018)

[23] G. Sutiyono, S. Muluk, Mafira, Tiza, dan R. Rakhmadi, "Indonesia's Village Fund: An Important Lever for Better Land Use and Economic Growth at the Local Level". Climate Policy Report. Available: https://climatepolicyinitiative.org. (Accessed 22 August 2019)

[24] Indonesia Corruption Watch (ICW), "Outlook Dana Desa 2018: Potensi Penyalahgunaan Anggaran Desa di Tahun Politik”, Available https://www.antikorupsi.org/sites/default/files/outlook desa 2018 - icw.pdf. (Accessed 22 August 2019)

[25] B. Sudaryana, "The Model of Development Policy Implementation of Village Owned Enterprises in Indonesia". Advances in Social Science, Education and Humanities Research (ASSEHR), volume 81. (2016)

[26] K. Srirejeki, "Empowering the role of Village Owned Enterprise (BUMDes) for rural development: case of Indonesia". Journal of Accounting, Management, and Economics, Vol. 20, No. 1, 2018, pp. 5-10. (2018)

[27] Law no. 32/2004 on Local Government

[28] Berdesa.com. "Ini Dia Lima BUMDES Terbaik di Pulau Jawa". 15 $5^{\text {th }}$ September. Available: http://www.berdesa.com/ini-dia-lima-bumdes-terbaik-di-pulau-jawa/. (Accessed 21 August 2019).

[29] Kumparan, “Kemendes PDTT: Separuh Lebih BUMDes di Indonesia Mati Suri”. 29 July 2018. Available: $\quad$ https://kumparan.com/tugujogja/kemendes-pdtt-separuh-lebih-bumdes-diindonesia-mati-suri-27431110790555989 (Accessed 22 August 2019)

[30] H. Sofyani, R. Atmaja, and S. B. Rezki, "Success Factors of Village-Owned Enterprises (BUMDes) Performance in Indonesia: An Exploratory Study". Journal of Accounting and Investment, 2(2): 44-58 (2019)

[31] Lapor.go.id, "Badan Usaha Milik Desa (BUMDes)". Available: https://www.lapor.go.id/laporan/kategori/badan-usaha-milik-desa-bumdes (Accessed 23 July 2019)

[32] E.Y.A. Gunanto, F. Arianti, B. Hayati, N. SBM, and Darwanto, "Strategy for the Development of Coastal Village Owned Enterprises (BUMDES) As a Form of Independent Village Development". International Journal of Mechanical Engineering and Technology (IJMET), 10 (6): 160-169. ISSN Print: 0976-6340, ISSN Online 0976-6359 (2019) 
[33] I. Nurhakim, and I. Yudianto, "Implementation of Village Fund Management in Payirapan Village, Sukanagara Village and Soreang Village, Soreang Sub-District, Bandung Regency". Journal of Accounting Auditing and Business, 2 (2): 34-47. (2018)

[34] J.C. Oi, "Two Decades of Rural Reform in China: An Overview and Assessment". The China Quarterly No.159, Special Issue: The People's Republic of China after 50 Years, pp.616-628. School of Oriental and African Studies. (1999)

[35] C. Xu, and X. Zhang, "The Evolution of Chinese Entrepreneurial Firms: Township-Village Enterprises Revisited". International Food Policy Research Intitute on April 2009. (2009)

[36] L. Sun, "Ownership Reform in China Township and Village Enterprise". Edited by Stephen Green and Guy S. Liu. Chapter 5, Chatham House/Blackwell Publishing, Oxford. (2007)

[37] X. Fu, and V. N. Balasubramanyam, "Township and Village Enterprises in China". The Journal of Development Studies. 39 (4): 27-46. Frank Cass London, London. (2003)

[38] B. Naughton, "The Chinese Economy: Transitions and Growth. MIT Press, Cambridge, ISBN10: 0-262-14095-0. (2007)

[39] J. Field, M. Garris, M. Guntupalli, V. Rana, and G. Reyes, "Chinese Township and Village Enterprises: A Model for Other Developing Countries". Paper for International Economic Development Program, Ford School of Public Policy, University of Michigan. (2006)

[40] E.C. Perotti , L. Sun, and L. Zou, "State-Owned versus Township and Village Enterprise in China”. Comparative Economic Studies. XLI (2-3): 151-179. (1999) 